\title{
Dolaysızlık ve Glitch Arasındaki İlişkiye Bir Bakış
}

\author{
Murat Yağız Aydın (Doktora Öğrencisi) \\ Anadolu Üniversitesi Sosyal Bilimler Enstitüsü \\ yagizaydin18@gmail.com \\ Orcid: 0000-0002-6065-1978
}

Başvuru Tarihi: 26.12.2018

Yayına Kabul Tarihi: 25.03.2019

Yayınlanma Tarihi: 22.07.2019

DOI: 10.17680/erciyesiletisim.503293

Aydın, Y. (2019). Dolaysızlık ve Glitch Arasındaki İlişkiye Bir Bakış. Erciyes İletişim Dergisi, 6 (2), 881-898. DOI: 10.17680/erciyesiletisim.503293

\section{Öz}

Sayısal teknolojiler gündelik yaşamımızı çevrelemiştir. Bu teknolojilerin her ne kadar insan yaşamını kolaylaştırdığı sık sık dile getirilse de aksaklıklar, kusurlar, hatalar daha geniş anlamda teknik bozulmalar sayısal teknolojilerin doğasına yerleşmiştir. Dolayısıyla gündelik yaşamda bu bozulmalarla karşılaşmak kaçınılmaz bir hal almıştır. Bazen şaşırtıcı bazen de alışılmış bir durum olarak görülen teknik bozulmalar, genelde olumsuz bir durum olarak görülmektedir. Ancak glitch sanatı bu aksaklıklardan faydalanarak hatalara olumlu bir önem atfetmeyi amaç edinir. Glitch kavramı hemen hemen aksaklık anlamına gelmektedir. Glitch sanatı, aksaklıktan ve gürültüden faydalanarak izlerkitlenin aracın farkına varmasını amaçlar. Üstelik bu farkındalıktan pozitif sonuçlar talep eder. Dolaysızlık ise iletişim sürecinde izlerkitleye aracın varlığını unutturmaya yönelik çağdaş bir arzudur. Bu çalışma glitch sanat ve dolaysızlık arasındaki ilişkinin ne olduğunu sorgulamaktadır. Bu iki olgunun özelliklerini tespit ederek aralarındaki ilişkiyi açığa çıkarmak bu çalışmanın genel amacıdır. $\mathrm{Bu}$ amaç doğrultusunda literatür tarama tekniği kullanılmıştır. Birinci bölümde glitch kavramının ne anlama geldiğine ve bu kavramla ilişkili olan, Claude Shannon ve Warren Weaver'ın iletişim sürecine dahil ettiği gürültü kavramına odaklanılmıștır. Daha sonra glitch sanatının ne olduğuna değinilmiștir. Bunun ardından Jay David Bolter ve Richard Grusin'in fikirleri doğrultusunda dolaysızlık kavramı açıklanmaya çalışılmıştır. Ayrıca bu bölümde konunun daha iyi anlaşılmasını sağlamak adına hiper dolayım ve düşünümsellik gibi kavramlardan da destek alınmıştır. Son olarak, glitch ve dolaysızlık arasındaki ilişki incelenmiştir. İnceleme sonucunda, bu iki olgunun birbirlerine karşıt eğilimler olduğu görülmüştür.

Anahtar Kelimeler: Glitch, Dolaysızlık, Glitch Sanatı, Gürültü, Hiper Dolayım. 


\title{
A View to Relationship between Immediacy and Glitch
}

\author{
Murat Yağız Aydın (Ph.D. Student) \\ Anadolu University Institute of Social Sciences \\ yagizaydin18@gmail.com \\ Orcid: 0000-0002-6065-1978
}

Date Received: 26.12.2018

Date Accepted: 25.03.2019

Date Published: 22.07.2019

DOI: 10.17680/erciyesiletisim.503293

\begin{abstract}
Digital technologies have surrounded our daily lives. Although it is frequently mentioned that these technologies make human life easier, malfunctions, flaws, errors and in broader sense technical malfunctions are inherent in digital technologies. In our daily lives, it is inevitable to face these malfunctions. Technical malfunctions which are seen as surprising sometimes and accustomed in others are often viewed as negative experiences. However, the purpose of glitch art is to benefit from these malfunctions to attribute positive importance to these errors. The word glitch is almost synonymous with distruption. The aim of glitch art is to enable audience to be aware of the tool by benefiting from malfunction and noise. Moreover, this art demands positive results from this awareness. Immediacy, on the other hand, is a modern desire that aims audience to forget the existence of the tool within communication period. This study investigates the relationship between glitch art and immediacy. The main aim of this study is to reveal the relationship between them by identifying the characteristics of these two notions, and the literature review is used to do this. In the first section, the concept of glitch and the concept of noise which is related with the glitch, and which is included by Claude Shannon and Warren Weaver in the communication process are focused. Then, glitch and glitch art are mentioned. After these definitions, immediacy is tried to be explained based on views of Jay David Bolter and Richard Grusin. Additionally, in this section to better explain the subject, support by concepts such as hypermediacy and reflexivity concepts is provided. Lastly, the relationship between glitch and immediacy is analysed. Analysis results show that when these two phenomenon have opposite tendencies.
\end{abstract}

Keywords: Glitch, İmmediacy, Glitch Art, Noise, Hypermediacy. 


\section{Giriş}

Glitch beklenmedik bir anda ortaya çlkan aksaklık, hata veya kusurun sonucudur. Günlük yaşamda sayısal teknolojileri kullanan her kullanıcının bir aksaklık, teknik bir hata, sayısal bir bozulma ile karşılașması neredeyse kaçınılmazdır. Bu aksaklıklar teknolojinin bir parçası haline gelmiştir. Sayısal dönemde glitch olarak da adlandırılan aksaklıklar gündelik yaşamda bir problem olarak görülür. Aksaklık sanatı olarak da bilinen glitch sanatı ise bu aksaklıklardan faydalanır. Bunu yaparken de aksaklıkların olumlu yanlarına dikkat çekerek eleştirel bir pozisyon alır. $\mathrm{Bu}$ eleştirel pozisyon yüksek teknolojinin karşısındadır. Glitch estetiği tekno-kültürün yerleşik ve ideolojik uzlaşımlarına, teknolojik ve algısal bir meydan okumadır. Ancak glitch estetiğinin eleştirel yanı, sadece göze güzel geldiği düşünüldüğü durumlarda görmezden gelinebilir. Bu eleştirel tutum, çağdaş medyanın aksine kusurdan, başka bir ifadeyle aksaklıklardan faydalanır.

Medya geliştiricileri ve programcılar sık sık teknolojinin kusursuzluğunu vurgulamaktadırlar. Daha da ileri giderek medyayı, kullanıcının ortamı ve aracın varlığını unutacak şekilde tasarlarlar. Bu bir bakıma kusursuzluğa erişme arzusudur. Aracın varlığını unutturmaya yönelik çağdaş arzu, yeni medyada "dolaysızlık" (Bolter ve Grusin, 2000) kavramıyla adlandırılmaktadır. Dolaysızlığa olan arzu, üstesinden kolayca gelinemeyen bir geçmişe sahiptir. Bolter ve Grusin dolaysızlığı tanımlamak için sanal gerçeklik teknolojisine başvurmaktadılar $(2000,22)$. Çünkü sanal gerçeklik, aracın izlerini ortadan kaldırmaya yönelik teknolojik girişimlerden biridir. Başka bir deyişle sanal gerçelik teknolojisi, kullanıcıya aracın varlığını unutturarak eksiksiz bir dolaysızlık ve oradalık hissini vermeyi amaç edinir. Bu teknolojide kusura yer yoktur. Diğer yandan bu teknoloji, medyanın çoğaldığı ve medyanın varlığının belirgin olduğu hiper dolayım mantığı gibi karşıt bir eğilimle karşılaşır. Bu karşıt eğilimin pozisyon açısından, yani dolaysızlığın altını oyması bakımından, glitch sanatının durduğu yerle benzerlik gösterdiği varsayılmaktadır.

Glitch ve dolaysızlık olgusu arasındaki ilişkinin ne olduğu bu çalışmanın problemini oluşturmaktadır. Bu iki olgunun özelliklerini tespit ederek aralarındaki ilişkiyi açığa çıkarmak bu çalışmanın genel amacıdır. Çalışmanın önemi iki temel noktada belirginlik kazanmaktadır. Birincisi, çağdaş bir medya eğilimi olmasına rağmen çalışmalarda eksikliği hissedilen dolaysızlık kavramını ele almasıdır. Diğeri ise tekno-kültüre eleştirel bir pozisyon alsa da literatürde eksikliği hissedilen glitch sanatını konu edinmesidir. Belki de daha da önemlisi, literatürde eksikliği hissedilen bu iki olguyu tek bir çalışma içerisinde ele almasıdır.

Çalışmanın amacı doğrultusunda öncelikle glitch kavramının ne olduğu ve Shannon ve Weaver'ın iletişim modelinin bir öğesi olan gürültü kavramı açıklanmıștır. Bunun sebebi, söz konusu iletişim modelinin, glitch kavramından daha önce literatüre kazandırılmış olması ve aynı zamanda glitchlerin ne olduğunu açıklamada temel bir başvuru noktası olmasıdır. Bu iletişim modelinde gürültü, enformasyon kaybına neden olan fiziksel ve teknik bir sorun olarak ortaya çıktığı için glitch kavramıyla yakından ilişkilidir. Bu değinin ardından birincil kaynaklar taranarak glitch kavramının ve glitch sanatının ne olduğu, hangi sanat akımlarından beslendiği açıklanmış, aynı zamanda ilk ve çağdaş örneklerine yer verilmiştir. Daha sonra, Jay David Bolter ve Richard Grusin tarafından çağdaş bir medya arzusu olarak adlandırılan, dolaysızlık kavramı açıklanmıştır. Dolaysızlık kavramını açıklarken bu kavramın ilişkili olduğu hiper dolayım kavramına değinilmiştir. Çünkü bu kavram, 
dolaysızlık ve glitch arasındaki ilişkinin açığa çıkarılmasına fayda sağlamıştır. Çalışmanın devamında literatürden elde edilen bilgiler doğrultusunda dolaysızlık ve glitch arasındaki ilişkinin ne olduğu incelenmiștir. Dolaysızlık ve glitch arasındaki ilişkiyi, bu ilişkinin yönünü ve iki olgunun karakteristik özelliklerini açığa çıkarmayı amaçlayan bu çalışmada literatür tarama tekniği kullanılmıştır.

\section{Glitch Nedir?}

Glitch kavramı, Türkçe'ye kusur, arıza, hata, bozukluk şeklinde çevrilebilir. Bu kavramın bu sözcüklerle birebir örtüştüğü ve hatta aksaklık, gürültü, sızma, kayma gibi sözcüklerle de ilişki içerisinde olduğu söylenebilir. Ancak bu çalışmada glitch kavramının bir çeviriye maruz kalmayıp yalnızca glitch olarak kullanılmasında fayda vardır. Bunun sebebi, glitch kavramına ilişkin getirilen tanımlarda veya bu kavramla ilgili ortaya çıkan sanat pratiği hakkındaki görüşlerde kavramın çevrilebildiği kelimelerin sık sık dile gelmesidir.

Glitch kavramının ne olduğunun anlaşılır kılınmasında bir sözlüğe, bir çeviriye başvurmanın dar bir bakış açısı sunacağı açıktır. Bunun için bu kavramın ve glitch sanatının tanımı konusunda literatüre başvurmakgereklidir. Bir glitch teorik, bilimsel ve sanatsal olmayan bir anlamda, beklenmeyen bir aksaklığın sonucu kabul edilir (Moradi, 2004, 9). Bu sözcük, ilk olarak 1962 yılında NASA astronotu John Glenn'in teknik problemleri tanımladığı yazılarla kayda girmiștir. Astronotlarca benimsenen bu kelimenin teknik anlamını veren Glenn için glitch, "bir elektrik akımında gerilimin aniden artması veya değișmesidir" (American Heritage Dictionary, 3111). Yani bir anlamda glitch her zaman bir problemin tanımıyla ilişkilendirilmiştir.

Norveç’te, 2002 yılında düzenlenen glitch sempozyumunun tanıtımında glitchin, "bilgisayar ve ağ terminolojisinde sürçme, kayma, düzensizlik, aksaklık ve küçük elektrik hatası anlamına gelen yaygın bir ifade" (Motherboard, 2002) olduğu belirtilmiştir. Rosa Menkman ise Glitch Moment(um) adlı kitabında glitchi sayısal sistemlerde meydana gelen, algılanan bir kaza, bir hata veya geleneksel bilgi akışından bir kopuş olarak tanımlamaktadır $(2011,9)$. Menkman'a göre "bir glitch teknik ya da sosyal anlamda anlaşılan, düzgünce çalışması beklenen bir işlevselliğin eksikliği veya aksaklığı sonucu ortaya çıkar. Bu yüzden, bir glitch kesin surette sadece teknik bir arızanın neticesi değildir" (2011, 9). Glitchin beklenmeyen veya istenmeyen bir aksaklık olduğu açıktır. Bir sistemdeki aksama, parçalanma anlamına gelen glitch tekil olarak bir sisteme bağlanamaz. Bir teknolojik sistem içerisindeki protokolleştirilmiş veri akış(lar)ından kopuş olarak dikkate alınabilir (Menkman, 2011, 26).

$\mathrm{Bu}$ kavram literatüre girmeden önce, iletişim çalışmalarında da fiziksel veya teknik bir aksaklık olarak adlandırılan gürültü (noise) kavramıyla karşımıza çıkmaktadır. Glitch sanatının neyi ifade ettiğine geçmeden önce Claude Shannon ve Warren Weaver tarafından iletişim sürecine dahil edilen gürültünün ne olduğuna, iletişim sürecinde ne gibi bir rol oynadığına bakmakta fayda vardır. Çünkü gürültü de glitch gibi istenmeyen, beklenmeyen fiziksel ve teknik bir aksaklığa işaret etmektedir.

\section{1. İletişim Çalışmalarında Gürültüye Teknolojik Bir Yaklaşım}

Claude Shannon ve Warren Weaver, 1949 yılında ortaya koydukları iletişim modeliyle akademik bir disiplin olarak iletişim çalıșmalarının başlangıcına öncülük etmişlerdir. İkinci Dünya Savaşı'nın sürdügü yıllarda geliştirilen ve Matematiksel İletişim Teorisi olarak bilinen bu model, Shannon'ın Amerika'da, Bell Telefon Şirketi'nde bir elektrik 
mühendisi olarak çalıştığı zamanlarda temel bir matematiksel iletişim modeli olarak geliştirilmiştir. Shannon'ın asıl amacı iletişim kanallarını en verimli biçimde kullanılabilecek yolları keşfetmektir. Söz konusu modelde iletişim, bir enformasyon aktarım sürecine indirgenir ve doğrusal bir süreç olarak ele alınır (Fiske, 2003, 21).

$\mathrm{Bu}$ modelin "önemli noktalarından biri, gürültü kaynağının iletişim sürecinde oynadığı roldür” (Özçetin, 2018, 139). Gürültü, bu süreç boyunca kaynağın isteği dışında gönderici ile alıcı arasındaki sinyale eklenen her şeydir. Aynı kanalda birçok sinyalin olması halinde gürültü meydana gelir. "İleticilerin gönderilen ve alınan mesajın her zaman tıpa tıp aynı olmayacağını fark edememeleri iletişimin başarıya ulaşamamasında önemli bir etken olarak görülür" (McQuail ve Windahl, 2005, 3132). Gürültü kaynağı, telefon kablosundaki hışırtı, radyo sinyalindeki parazit ya da televizyon ekranındaki karıncalanma gibi "iletişim akışını olumsuz etkileyen teknik ve fiziksel sorunlar" (Güngör, 2013 61) olarak düşünülebilir.

Shannon ve Weaver, iletişim araştırmalarında üç sorun düzeyinden söz etmektedirler. A düzeyindeki gürültüler (teknik sorunlar) onların temel odak noktalarıdır. $\mathrm{Bu}$ yüzden $\mathrm{B}$ düzeyindeki anlamsal gürültüleri teknik gürültüden ayırırlar. Teknik gürültü iletişimin hangi aşamasında kaynaklanırsa kaynaklansın "göndericinin niyetinde daima bozulmaya neden olur ve dolayısıyla verili bir anda, verili bir konumda gönderilebilecek arzu edilen enformasyon miktarını sınırlar" (Fiske, 2003, 24). Bununla birlikte, bu iletişim modelinde enformasyonun sadece gürültüden etkilenmediğini ve doğru aktarım için gürültüye bağlı olduğunu fark etmek önemlidir. Başka bir ifadeyle, bu modelde enformasyon gürültüyle sadece suç ortaklığı yapmaz, aynı zamanda bir aydınlanma veya izah olarak ortaya çıkar. Weaver'a göre; gürültü meydana gelirse alınan mesaj, bozulmalar, belirli hatalar, belirli yabancı maddeler içerir ki bu durum kesinlikle alınan mesajın, gürültünün etkileri yüzünden, artan belirsizliğin ortaya çıkışına vurgu yapar. Ancak belirsizlik artarsa, bilgi artar ve bu faydalıymış gibi algılanır (Aktaran: Nunes, 2011,22). Gürültü olmaksızın ya orijinal mesaj içinde kodlanmış ya da kanal dışındaki kaynaklarda mevcut, işleyen bir kanal olamaz. Yani, "gürültü olmaksızın bilgi olmaz" (Ballard, 2011, 67).

Shannon ve Weaver'ın iletişim modeli bugün hala geçerlidir. Onların iletişim modeli ve modelin aşamaları 21. yüzyıl içerisinde değerlendirildiğinde güncelliğini korumaktadır. Gürültü kavramı sayısal dönemde glitch kavramıyla ya anılmakta ya da özellikle glitch sanatı pratiği içerisinde yakın anlamlara gelmek üzere kullanılmaktadır.

\section{Glitch Sanatı}

Iman Moradi, 2004 yılında yazmış olduğu tezinde glitch sanat çalışmalarının üretimi ve sunumunda yaygın ve farklı pratikleri kapsayan bir tanımlamaya girișir. Bu doğrultuda glitch tanımını yaparken iki terim üzerinden hareket eder. Saf (pure) glitch ve glitch-benzeri. Saf glitch, aksaklık veya hatanın bir sonucudur. Daha açık bir ifadeyle saf glitch kendi içerisinde estetik bir değer barındıran veya barındırmayan, önceden tasarlanmamış veya planlanmamış sayısal bir eserdir $(2004,10)$. Glitch sanatçıları, sayısal ortamlarda aksaklıkları sentezler ya da bir glitchi başlatması gereken veya bir glitchin meydana gelmesini sağlayacak ortamı üretir ve yaratırlar. Glitch-benzeri ise bu pratiğin, kavramın açıklayıcısı olarak konumlandırılır. Dolayısıyla glitch-benzeri çalışmalar, orijinal ortamlarında bulunan gerçek glitchlerin görsel yönlerini andıran, sayısal olarak üretilmiş eserler dizisidir. 
Başka bir ifadeyle glitch-benzeri, bir glitch beklentisiyle oluşturulan, planlanmıș, tasarlanmış bir üretim pratiğidir (Moradi, 2004,10). Moradi bu iki kavram altında bir de siniflandirma yapar:

\begin{tabular}{|c|c|}
\hline Saf (Pure) Glitch & Glitch-benzeri \\
\hline Kazara (Accidental) & Bilerek (Deliberate) \\
\hline Tesadüfi (Coincidental) & Planlanmış (Planned) \\
\hline Glitche uygun (Appropriated) & Tasarlanmış (Designed) \\
\hline Bulunmuş (Found) & Yaratılış (Created) \\
\hline Gerçek (Real) & Yapay (Artificial) \\
\hline
\end{tabular}

Menkman'a göre prosedürel bir akış bozulur bozulmaz, glitche yönelik iki muhtemel eğilim vardır. Makinenin düzensiz çalışmasının nedeni biliniyorsa, glitch bir uyarıcı olarak işlev görür ve bir arızanın basit bir hata raporu haline gelir. Ĕger glitchin nedeni bilinmiyorsa, glitch gözardı edilebilir, unutulabilir ya da bozuk olan teknolojik, sosyal ya da kültürel bağlam içerisinde bir yorum veya düşünceye dönüștürülebilir (2011, 27). Mennasemay ve arkadaşlarına göre bir glitch şu sözlerle ifade edilmektedir:

Doğal ve sosyal bilimler, beșeri bilimler ve yaratıcı sanatlar, ve yașam deneyimleri boyunca bir çok şeyde bulunabilir. Metodolojide bir kayma. Kabul edilmeyen bir önyargı. Hatalı bir varsayım. Bir argümandaki mantıksızlık. Kabul gören bir teoriye zit düşen deneysel bir sonuç. İstenmeyen bir sonuç. Bir melodideki beklenmeyen bir nota. Bir filmdeki çekim hatası. Bilişsel uyumsuzluk anı. Estetik uyumsuzluk. Görünen bir irrasyonellik. Belirgin bir saçmalık. Görünür bir imkansızlık. Her durumda glitch hem negatif hem de pozitif olarak görülebilen sonuçlara neden olmanın yanı sıra hem büyük hem de küçük etkilere neden olabilir ve bize öncülük eden yolları sorgulamamızı, araştırmamızı ve yaratıcılığımızı yeniden yönlendirebilir $(2017,2)$.

Sayısallaşma ile beraber sayısal cihazlarda, ortamlarda ve iletişimde yaşanan "küçük/ büyük veri kayıpları ve sinyal bozulmalarının bütün sistemi etkilemesi teknolojik sistemlerin dayanıklılığının sorgulanmasını" gerektirmiştir (Somer, 2013). Özellikle 1990'lardan itibaren internetin kitlesel bir medya olarak yükseliş göstermesiyle yeni sayısal bozukluklar yaygınlaşmıştır (Betancourt, 2014). Günlük yaşamda sayısal teknolojileri kullanan her bir kullanıcının sayısal bir aksaklık ile karşılaşması neredeyse kaçınılmaz olmuştur. Bu hatalar, bozukluklar veya aksaklıklar sayısal teknolojinin ortak bir parçası haline gelmiştir. Glitch sanatı her ne kadar sayısal teknolojilerin gelişiminin ardından teorik ve pratik anlamda var olsa da, köklerinin sayısallaşma öncesine dayandığı söylenebilir.

Glitch sanatının Fütürizm, Soyut Sanat, Dada, Happenings (oluşumlar) ve Kavramsal Sanat ile başlayan DJ kültürü, remix ve hacking ile ilişkili olan uzun bir sanatsal geleneğin parçası olduğu ifade edilebilir. Glitch sanatını meşrulaştırmak için ise Dada, Sürrealizm ya da Fluxus gibi avant-garde akımların yaratım ve yıkım durumlarıyla ilişkilendirmek faydalı olabilir (Grundell, 2016, 23). Örneğin, modernist sanatçılar dünyayı olduğu gibi yansıtmayı reddederler. Resmi, bir temsil olmaktan ziyade kanvas üzerindeki bir çalışma olarak görürler. Benzer şekilde glitch sanatı, analog veya sayısal teknolojilerin temsili özelliklerini açığa çıkarır ve temsilin doğasına yıkıcı bir şekilde meydan okur. Tıpkı çağdaş sanat da olduğu gibi glitch sanatçıları da yeni bir şey üretmekle ilgilenmezler, bundan ziyade hali hazırda varolan bir şeyi vurgular ve/ veya dönüştürürler (Grammatikopoulou, 2014). Örneğin, Marcel Duchamp sanatını icra ederken hazır (ready-made) nesneler aramıştır. Fluxus sanatçllar da olduğu gibi, glitch sanatçllar için de estetik düşüncelerden ziyade, toplumsal kaygıların önce 
geldiği söylenebilir. Yine Fluxus'da olduğu gibi glitch sanatta da rastlantıya önem verilir. Özetle, aksaklık estetiği sayısal teknolojilerin hızla yaygınlaşmasına paralel olarak hata sayısının da arttığı modernist ve çağdaş kültür içerisinde yıkıcı ve itici bir güç olarak doğmuştur.

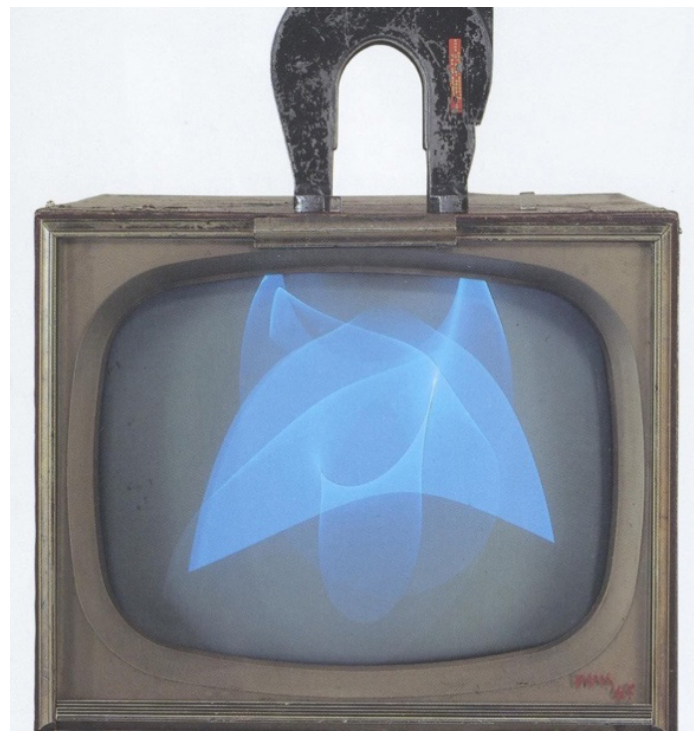

Şekil 1: Nam June Paik, MagnetTV (1964)

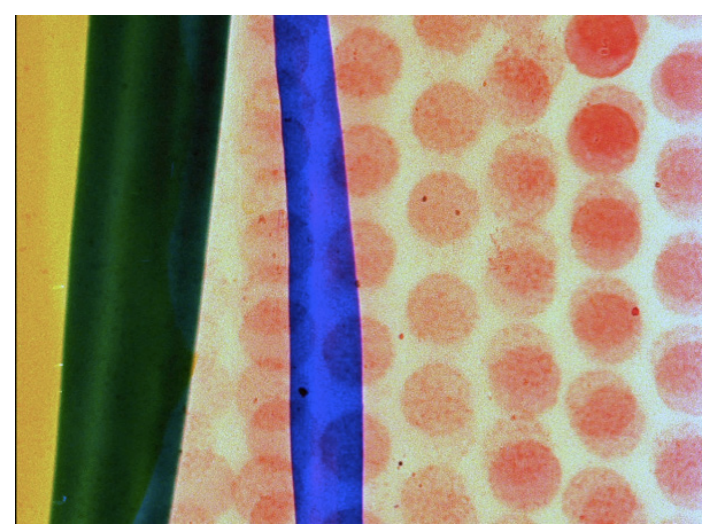

Şekil 2: Lin Lye, A Color Box (1935) Kaynak: https://oss.adm.ntu.edu.sg/yihan001/tag/magnet-tv/ Kaynak: http://cargocollective.com/flatsurface/Len-Lye

Glitch sanatı aslında yeni değildir. Her ne kadar teknik aksaklıklar, bozulmalar ve hataların glitch olarak adlandırılıp kabul görmesi 2000'li yıllardan itibaren gerçekleşse de, daha geçmiş yıllara gidildiğinde görsel sanatlarda Lin Lye'ın A Colour Box (1935) ve Nam June Paik'in MagnetTV (1965) adlı çalışması glitch sanat pratiği içerisine konumlandırılabilir.

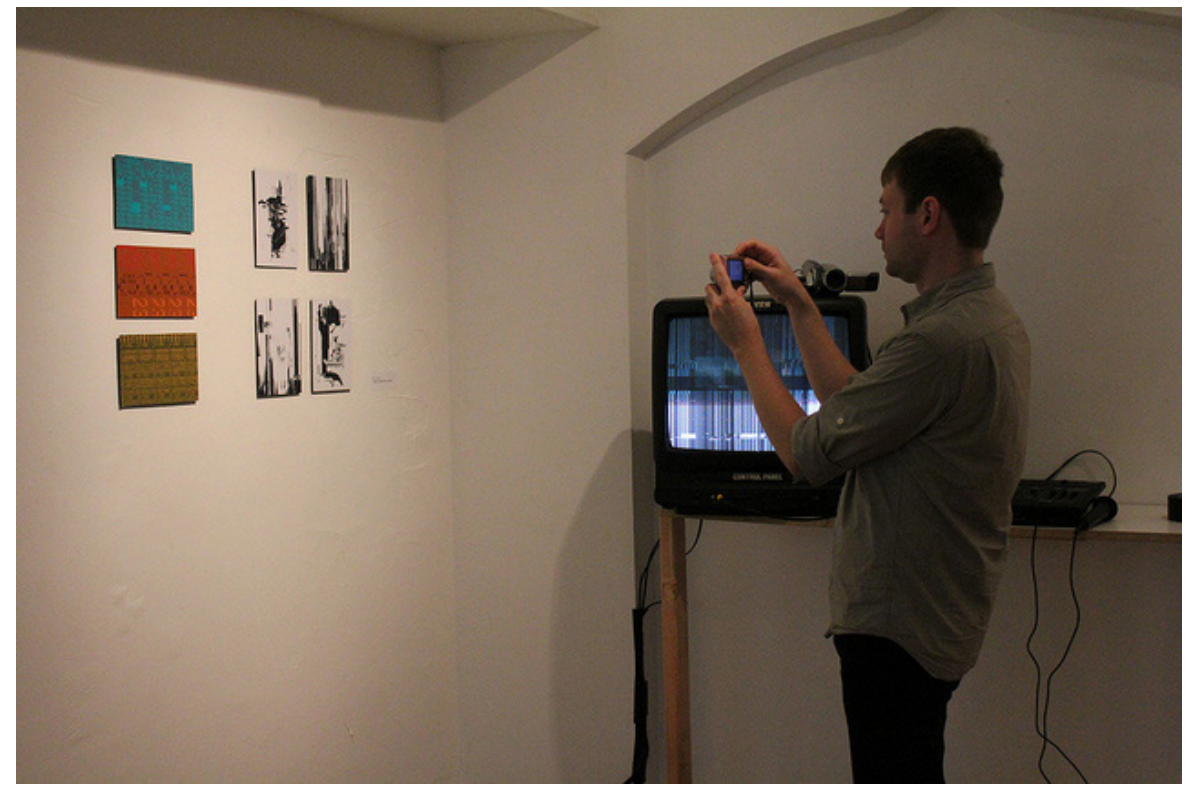

Şekil 3: Ant Scott ve dijital glitch baskllarl

Kaynak: https://www.flickr.com/photos/r00s/5044447933/in/photostream/

Çağdaş bir örnek olarak Ant Scott'ın çalışmaları saf glitche birer örnektir. Çünkü bu görüntüler bilgisayar kaynaklı arızalarla, yazılım hatalarıyla, hacklenmiş veya modifiye edilmiş oyunlarla ortaya çıkmıştır (Menkman, 2011, 34). 

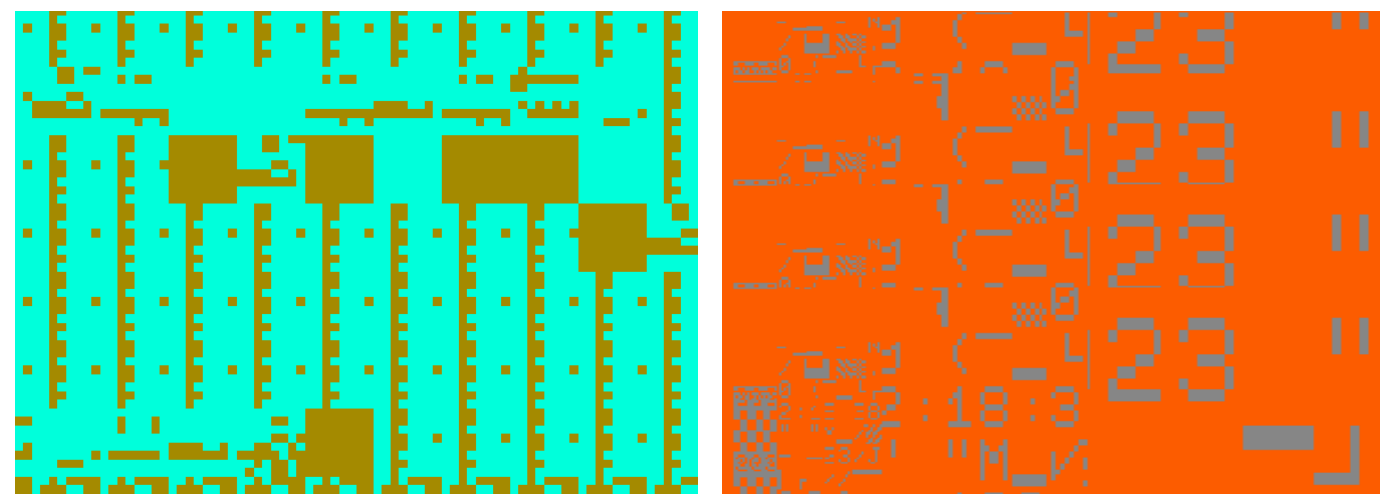

Şekil 4: Ant Scott'ın Beflix serisinden bir glitch Şekil 5: Ant Scott'ın Beflix serisinden bir glitch Kaynak: http://www.beflix.com Kaynak: http://www.beflix.com

2007 yllında ise Cory Arcangel, Panasonic TH42PV60 Plasma Screen Burn adlı çalışmasında (Şekil 3) Panasonic bir plazma ekranda yazıları uzun süre tutarak LCD olan ekranın yazılı kısımlarını yakar ve daha sonra ise yazılar kalıcı olarak ekrana gömülü kalır. Verili bu örnek saf glitch olmaktan yoksundur; tasarlanmış, planlı ve yapay bir glitch (benzeri) çalışmasıdır.

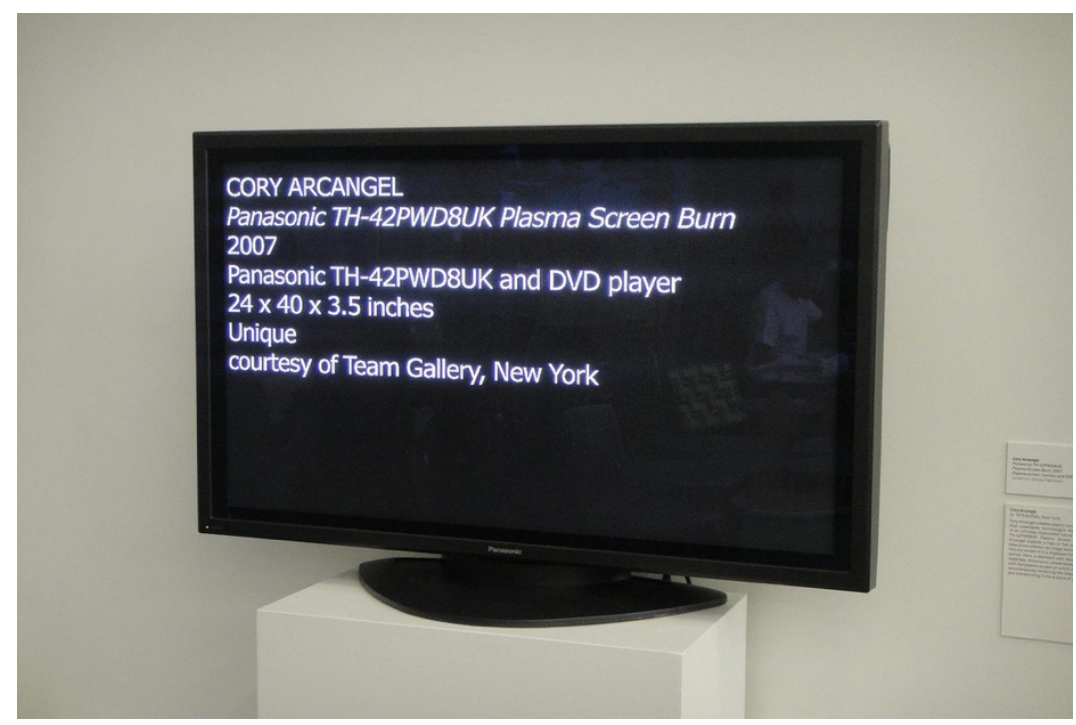

Sekil 6: Cory Arcangel - Panasonic TH-42PWD8UK Plazma

Kaynak: https://www.flickr.com/photos/yotam_hadar/3590874521

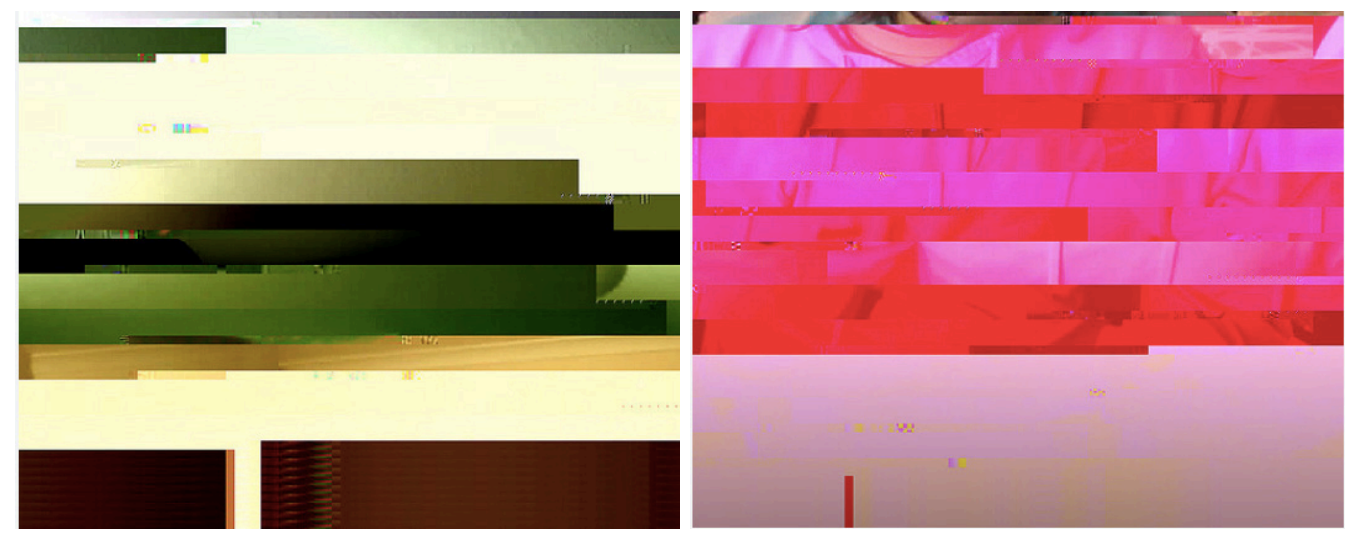

Şekil 7: Justin Windle'ın “Glitch Cam” serisinden örnekler Kaynak: https://www.flickr.com/photos/soulwire/sets/72157603055370065/ 
Tesadüfi glitche örnek olarak Justin Windle’ın Glitch Cam (Şekil 6) adlı serisi örnek verilebilir. Windle, Windows Vista işletim sisteminin web-kamerasının sürücülerini otomatik yüklemesine izin verince; web-kameradan çekilen fotoğraflar bir glitch olarak ortaya çıkar.

Glitch sanata bir başka örnek ise Hollandalı sanatçı Jodi'nin Untitled Game (Şekil 7) adlı çalışmasıdır. Menkman, Glitch Moment(um) adlı kitabında bu çalışma üzerine ciddi bir şekilde eğilir. Bunun temel sebebi ise Jodi'nin sadece estetik kaygllarla hareket ediyor olmamasıdır. Untitled Game Jodi tarafından, kasıtlı bir şekilde yıkıma uğratılmış Quake 1 adlı video oyunun bir modifikasyonudur. Jodi, Quake 1 adlı oyununun kodları ve grafikleri üzerinde değişiklikler yaparak, oyunu çalışmasına rağmen yıkıma uğratmış bir şekilde geliştirmiştir $(2011,40)$.

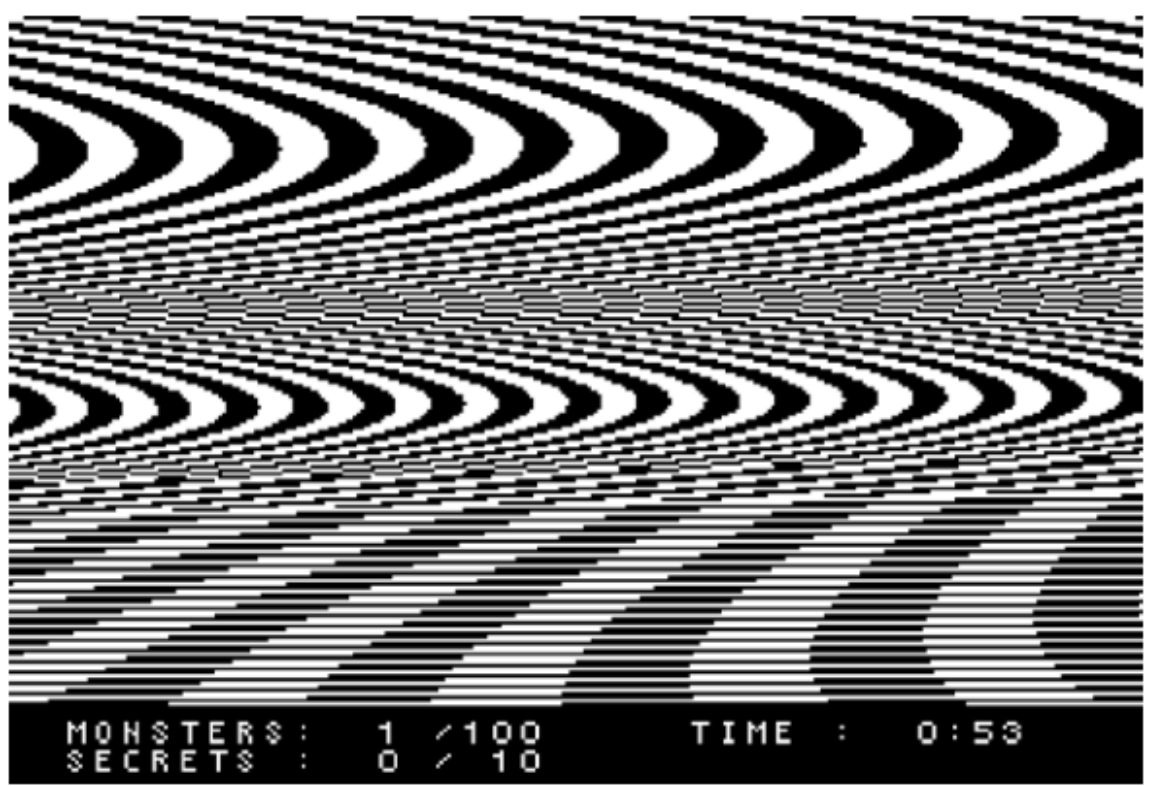

Şekil 8: Jodi, Untitled Game adlı oyun modifikasyonundan bir görüntü Kaynak: (Menkman, 2011, 38).

Bu glitch eseri, video oyununun uzlaşımsal ve normatif amaçlarını sorgular. Oyunun değiştirilmiş algoritması, görselleri ve seslerinin manipüle edilmesindeki amaç, yeni anlamlar ve uzlașımlar yaratmaktır. Dolayısıyla oyunun sonucu artık puan değil, renkli ve rahatsız edici bir deneyim haline gelir (Menkman, 2011, 39). Menkman'a göre, Jodi'nin çalışması medya sistemlerinin hegemonik akışına karşı savaş veren, yıkıcı bir glitch sanatı örneğidir. Aynı zamanda Untitled Game oyun teknolojisine, tüketimine, oyun ortamına, özel bir şekilde hazırlanmış tasarıma karşı bir isyan girişimidir. Jodi yüksek teknolojiye karşı savaşır, aynı zamanda grafiksel bir seviyede bilgisayarla savaș halindedir $(2011,42)$.

Jodi, programın akışını, arayüzünü ve onun geleneklerini eleştirir. Platformun türüne, biçimine ve tekniğine uymayarak Quake 1'i yeniden şekillendirir. $\mathrm{Bu}$ modifikasyonla birlikte kullanıcı belirli veya ticari bir oyunun uzlaşımsal çerçeveleri üzerinde düşünmeye sevk edilir. Bu tür çalışmalar medya ve teknoloji tüketicisinin bu sistemlere yönelik algısını yeniden şekillendirirler. Bunu da kullanıcı/izleyiciyi politik bir şekilde provoke ederek gerçekleştirirler.

Bir glitch, karanlık ya da aydınlığa izin veren bir açıklık olabilir. Görülmeyen, gizli bir anormallikteki sinyalizasyon; bastırılmış bir deneyim, duygu ve fikir, hatta 
sistemdeki beklenen kaoslara, yerleşik bir kuramın veya inancın çöküşüne, toplumsal ve kişisel ilişkilerin yok olmasına izin veren bir çatlak olabilir (Mennasemay ve diğerleri, 2017, 2). Glitch kimi zaman küçük, önemsiz gibi görünebilir ve unutulabilir. Ancak sistemlerde meydana gelecek bir glitch hayal ettiğimizden daha derinde işlev görebilir ve beklediğimizden daha ciddi sonuçlara yol açabilir. Bunun da ötesinde bir glitch "yeni soruları ve yeni anlayış biçimlerini gündeme getirebilir. Yeni görme biçimlerini ve hatta bir bilimdeki paradigma değişimine veya yeni estetik hassasiyetlerin doğuşuna neden olabilir" (Mennasemay ve diğerleri, 2017, 2).

Glitch veya gürültü estetiği medya sistemlerinde, tekno-kültürde varolan yerleşik ve ideolojik uzlaşımlara teknolojik ve algısal bir meydan okuma olarak dikkate alınabilir. Medya geliştiricileri ve programcılar teknolojiyi kullanıcının ortamın ve aracın varlığını unutacak şekilde tasarlarlar. Aracın varlığını unutturmaya yönelik arzu, yeni medyada dolaysızlık kavramıyla adlandırılmaktadır.

\section{Dolaysızlık Nedir?}

Bolter ve Grusin, Remediation adlı kitapta yeni medyanın belirgin özelliklerini tanımlarlar. Bunlar, yeniden dolayımlama (remediation), dolaysızlık (immediacy) ve hiper dolayımdır (hypermediacy). Bolter ve Grusin'e göre yeniden dolayımlamanın iki temel mantığı, dolaysızlık ve hiper dolayımdır. Bu iki mantık Rönesans'a kadar uzanan köklü bir geçmişe sahiptir. Dolaysızlık mantığı Rönesans'tan günümüze kadar kendini gösterir, ancak tezahürü çağdan çağa önemli ölçüde farklılık gösterebilir; "kuramcllara bir şey, sanatçılara veya tasarımcılara başka bir şey ve izleyicilere üçüncü bir şeyi ifade edebilir” (Bolter ve Grusin, 2000, 21). Şeffaf dolaysızlık arzusuna tarihsel bir karşılık olarak medya veya dolayıma düşkünlük aydınlatılmıș Orta Çağ el yazmaları, Rönesans altar panosu, Flemenk resim sanatı, barok dolapları, modernist kolaj ve fotomontaj gibi farklı biçimler içerisinde bulunabilir (Bolter ve Grusin, 2000, 34).

Dolaysızlığın en basit tanımı onun amacıyla anlaşılabilir. Bu amaç, izleyicinin veya kullanıcının, ortamın (tuval, film, bilgisayar vb.) varlığını unutmasını sağlamaktır. Bunun da ötesine geçerek izleyicinin ortamın içinde olduğuna inanmasını sağlayan veya oradalık hissini veren görsel bir temsil tarzı ortaya koymaktır (Bolter ve Grusin, 2000, 272-273). Böyle bir temsil tarzında dolaysızlık, temsil kendisini bir şey olarak algılasın diye, gösteren ve gösterilen arasındaki aralığın ya da izin kusursuzluğudur. Böylece temsil gerçeğe açılan bir pencere olarak algılanır.

Bolter ve Grusin, dolaysızlığı tanımlarken sanal gerçeklik teknolojisine başvururlar. Onlara göre, "sanal gerçeklik çevreleyendir" (2000, 21). Kullanıcısını çevreleyen özelliğiyle aracı ortadan kaldırmayı amaçlar. Sanal gerçekliğin amacı, izleyicide oradalık ve varoluş hissini sağlamaktır. Bolter ve Grusin, dolaysızlığı tanımlarken bir bilim kurgu filmi olan, Strange Days adlı filme başvururlar $(2000,22)$. Bu filmde ana kahraman, sanal gerçeklik kaskı takıldığında izlenilebilen kasetler satmaktadır. Bu teknoloji başkalarının anılarını onların gördüğü ve duyduğu gibi deneyimlemeyi mümkün kılmaktadır. Kaskı takan kullanıcı, kaskı daha önce takan kullanıcının anılarını yeniden deneyimleyebilmektedir. Onlara göre, Strange Days filmindeki sanal gerçeklik teknolojisi "milenyumun sonundan önce yaratılan en son ve en muhteșem teknolojidir" $(2000,24)$. Bolter ve Grusin bu dolaysızlık arzusuna ve bu filme ilişkin şu sözleri dile getirirler: 
Dijital teknolojiler, kültürel, legal ve eğitim kurumlarımızdan daha hızlı çoğalarak onlarla iş birliği yapabilir. Kültürümüzün dolaysızlık ve hiper dolayım için karşıt gerekliliklerini ele alırken, bu film bize yeniden dolayımlamanın iki mantığı dediğimiz şeyi sergilemektedir. Kültürümüz hem araçları çoğaltmak hem de aracılamanın tüm izlerini silmeyi arzular: bunun ideal olan biçiminde, aracı hemen çoğaltma girişiminde medyayı ortadan kaldırmayı arzular (Bolter ve Grusin, 2000, 5).

Mevcut sanal gerçeklik teknolojileri yetersiz olarak düşünülebilir. Bunun sebebi bu teknolojinin hala aygıtlara ihtiyaç duymasıdır. Bu durum aracın ortadan kaybolmamasındaki temel etkendir. Eksiksiz bir dolaysızlık hissi ya tamamen aracın kaybolmasına ya da izleyici ve kullanıcının araç orada yokmuş gibi hissetmesine bağlıdır denebilir. Daha da basite indirgenirse, sanal gerçeklik aracı ortadan kaldırmak istemektedir, fakat aynı zamanda medyanın çoğaldığı ve medyanın varlığının belirgin olduğu karşıt bir eğilimle karşılaşır. Dolayısıyla aracın izleri kalmaya devam ettiği sürece, eksiksiz bir dolaysızlığa erişmek mümkün değildir (Dobson, 2006, 2).

Bolterve Grusin, dolaysızlığı sanal gerçekliğin yanı sıra, bilgisayar, film ya da televizyon ekranında da bulurlar. Örneğin, bir bilgisayarın, bir ofis çalışanının masasının üzerindeki materyalleri barındırmasından ötürü fiziksel masaüstüne benzediği farzedilir. Bilgisayarda gelenekselleşmiş masaüstü, fiziksel ofis masaüstünün bir metaforudur. Bilgisayar tasarımcılarının yıllardır arzu ettikleri şey herhangi bir aracın farkedilmediği "arayüzsüz bir arayüzdür" (Bolter ve Grusin, 2000, 23). Bu da arayüzü kontrol etmeye, arayüz üzerinde işlem yapmaya yarayan araçların ortadan kaybolması anlamına gelir. Bu durum dolaysızlığa duyulan tarihsel arzunun bir başka göstergesidir.

Bolter ve Grusin'e göre hem sanal gerçeklik, hem üç boyutlu grafikler hem de grafiksel arayüz tasarımı sayısal teknolojiyi tamamen şeffaf kılmaya çabalamaktadır. Şeffaf bir arayüzle birlikte, kullanıcı bir araçla yüz yüze gelmesin diye arayüz kendini yok eden bir şey olacaktır. Buna paralel olarak aracın içerikleri ile dolaysız bir ilişki içerisinde olmaya devam edecektir. Şeffaf arayüz, dijital teknolojinin aracılık eden özelliğini tamamen reddetme ihtiyacının birçok göstergesinden biridir $(2000,23)$. Sayisal araç, sanki izleyici orijinal araçla yüz yüze gelmiș gibi, içeriğe aynı alakayı göstersin diye kendini yok etmek ister. İdeal olarak bilgisayar ekranı üzerinde ve kişide bir resmi görme deneyimi arasında fark olmamalıdır. Ancak bu hiçbir zaman böyle olmaz. Belki izleyicinin bir butona tıklaması veya resmin tamamını görmek için bir çubuğu kaydırması gerektiği için veya belki de dijital görüntü bozuk veya grenli bir şekilde ortaya çıktığı için, bilgisayar daima bir şekilde müdahaleci davranır ve varlığını hissettirir. Ancak şeffaflık, geriye amaç olarak kalır (Bolter ve Grusin, 2000, 23).

Sinemaya gelindiğinde, gerek animasyon filmlerinde gerek yüksek bütçeli filmlerde, özel sinema efektlerinin ve grafiklerin yapımında da dolaysızlığın hedeflendiği görülür. Grafik animasyonlarla yapılan Toy Story gibi örneklerde veya özel efektlerin kullanıldığı sinema filmlerinde amaç, bilgisayarın izlerini ortadan kaldırmaktır (Bolter ve Grusin, 2000, 47). Bilgisayar izlerini ortadan kaldırmak demek ortamın, nesnelerin ve karakterlerin mümkün olduğunca gerçek oyuncularla çekilmiş gibi, canlı çekim süsü verme amacı anlamına gelir. Bir sinema filmindeki dinozorun, canavarların, uzayın, gezegenlerin gerçekmiş gibi gösterilmesi arzusu bu duruma bir başka örnektir. Ancak dolaysızlık arzusu, üstesinden kolayca gelinmeyen bir geçmişe sahiptir. Bu arzu, en az Rönesans'tan beri Batı görsel temsilinin tanımlanan 
bir özelliğidir. $\mathrm{Bu}$ arzunun karşısında kendini konumlandıran durum ise hiper dolayımdır. Peki nedir hiper dolayım?

Hiper dolayım, izleyiciye aracın varlığını hatırlatmayı amaçlayan görsel bir temsil biçimidir (Bolter ve Grusin, 2000, 272). Hiper dolayımın ham içerikleri herhangi bir kombinasyonda bir araya getirilebilen görüntüler, sesler, metinler, animasyonlar ve videolardır. "Hiper dolayım, 'rastgele erişim' sunan bir araçtır; hiçbir fiziksel başlangıca, orta kısma ve sona sahip değildir" (Bolter ve Grusin, 2000, 39). Bu durum aklımıza günlük hayatın bir parçası olmuş internet deneyimini getirir. Hiper dolayımın en basit örneği seslere, fotoğraflara ve videolara erişime imkan vermenin yanı sıra bir çok öğeyi içinde barındıran web sayfalarıdır. Bolter ve Grusin'e göre de "bugün dijital medyada hiper dolayım uygulaması internet sunucu sayfalarının heterojen pencereli biçimlerinde, masaüstü arayüzlerinde ve video oyunlarında çok belirgindir" $(2000,31)$.

Bazı zamanlarda hiper dolayım, "dolaysızlık arzusunu hem kabul ederek hem de altını oyarak, oynak ya da yıkıcı bir tavır benimsemektedir" (Bolter ve Grusin, 2000, 34). Hiper dolayım, dolaysızlık arzusunu sarsarak izleyicinin görme biçimini hiper bilinçli hâle getirir. Dolaysızlık, canlı bir medya olayına bir pencere açmayı arzulayan bir tavra sahipken, çoklu ortamlı hiper dolayımın ilgisi ise izleyicinin aracılanmış medya deneyimine eriștiğinin farkındalığını vermektir. Ancak bu iki mantık bir arada bulunabilir. Hem dolaysızlı hem de hiper dolayım internet ve bilgisayar teknolojilerinin pencereli stilini yansitırlar.

Kimi zaman birbirleriyle rekabet eden bu iki mantık arasındaki farkı daha iyi anlamak için Dobson'un oluşturduğu tabloya bakmakta fayda vardır:

Tablo 1: Dolaysizlık ve Hiper Dolayım (Dobson, 2006)

\begin{tabular}{|l|l|}
\hline Dolaysızlık & Hiper dolayım \\
\hline Pencere açar. & Pencereden baktıır. \\
\hline Epistemolojik olarak, bilgi şeffaflığa bağlıdır. & Epistemolojik olarak, bilgi opaklığa bağlıdır. \\
\hline $\begin{array}{l}\text { İzleyici -psikolojik olarak- aracın } \\
\text { izlerinin silindiğini hisseder. }\end{array}$ & $\begin{array}{l}\text { İzleyici -psikolojik olarak- aracın izlerinin } \\
\text { silinmediği izlenimine sahiptir. }\end{array}$ \\
\hline $\begin{array}{l}\text { Gerçeklik, (aracın açtığı pencereden temsil edildiği } \\
\text { gibi) sahici olarak deneyimlenir ve erişilen bir şeydir. }\end{array}$ & $\begin{array}{l}\text { Aracın deneyimi, gerçek ve } \\
\text { sahici deneyimin kendisidir. }\end{array}$ \\
\hline $\begin{array}{l}\text { Birleşik bir perspektiftir, normatif } \\
\text { doğrusal bakış açısı sunar. }\end{array}$ & $\begin{array}{l}\text { Medyayı çoğaltır ve izleyicinin perspektifini } \\
\text { parçalar, çarpıklık hissi verir, normatif ve } \\
\text { doğrusal perspektifin karşısında konumlanır. }\end{array}$ \\
\hline Odaklanmış bakış & Değişen bakış \\
\hline $\begin{array}{l}\text { Sanal gerçeklik ile uçma deneyimi } \\
\text { (pilot eğitim simulatörü) }\end{array}$ & Televizyon haberleri \\
\hline
\end{tabular}

Pek çok anlamda dolaysızlık mantığı düzen, birlik ve zaman zaman birleşik perspektif ve bakışla kazanılan kontrolü sürdürmek için modern bir kaygıyla yankılanır. Hiper dolayım ise postmodernin parçalama arzusuna karşılık gelir. Aynı zamanda, karşılıklı olarak hareketli bakış içerisinde birbirlerini yapıbozuma uğratan perspektiflerin çoğalmasına işaret eder (Dobson, 2006, 3).

Bolter ve Grusin televizyonun, film fotoğrafçılığı ve bilgisayar grafiklerinin sahip olduğu foto-gerçeklikten yoksun olduğunu ifade ederler (2000, 31-32). Çünkü televizyon yüksek çözünürlük ve görsel derinlikten yoksundur. Yüksek çözünürlüklü televizyonun gelişi ve ucuz oluşu bunu değiştirmiştir. Ancak televizyonun hâlâ 
fotoğraf ve filmi yeniden aracıladığı ve yorumladığı açıktır. Çünkü televizyon, filmin sunduğu 'orada ve o zaman'ın aksine, canlılıkla birlikte 'şimdi ve burada'lığı sunar. $\mathrm{Bu}$ durum televizyon için hem dolaysızlık ve hiper dolayımın kapasitesini yansıtır (Dobson, 2006). Bu noktada, dolaysızlık ve hiper dolayımın aynı medya içerisinde birbirlerine hem tamamen zit hem de birbirleriyle paralel bir şekilde işlev görebileceği anlaşılır. Günümüz yeni medyası geleneksel medyayı yeniden aracılarken bir yandan dolaysızlı̆̆ arzular diğer yandan izleyicinin medya deneyimini yaşayabileceği bir durum ortaya çıkarır.

$$
\begin{array}{r}
\text { “Çömlekçinin parmak izleri çanağa nasıl yapıșıp kalırsa, } \\
\text { anlatıcı da hikâyesinde öyle iz bırakır". } \\
\text { - Walter Benjamin, "Hikâye Anlatıcısı" }(2012,84)
\end{array}
$$

\begin{abstract}
“Eksiksiz bir dolaysızlık arayıșı medyanın daha yeni, 'daha iyi' olmasına neden olmasına rağmen, her arayış daima kendine ait kusurun parmak izlerini bırakacaktır. Çoğu insan bu parmak izlerini olumsuz olarak (hatta bazen de kaza) deneyimlerken, bu parmak izlerinin sunduğu yeni firsatları gösererek onları olumlu sonuçlarını vurgulamaktayım”.
\end{abstract}

- Rosa Menkman, Glitch Moment(um) (2011,11)

\title{
5. Dolaysızık ve Glitch Arasındaki Ilişsiye Bir Bakış
}

Glitch ve dolaysızlık arasında ilişkinin ne olduğunu anlayabilmek için iki pratiğin tanımları ve çağdaş medyadaki karakteristiklerine odaklanmak gerekir. Bunun ardından bu iki pratiğin birbirlerine hem karşıt hem de benzer özellikleriyle karşılaşılabilir. Bu kıyaslamayı yapmak ve sonuçları görmek için, Bolter ve Grusin'in dolaysızlığı tanımlarken yaptığı gibi, sanal gerçeklik teknolojisine başvurmak bir sıçrama tahtası olabilir. Çünkü sanal gerçeklik dolaysızlığı arzulayan, daha doğrusu ona ihtiyaç duyan görsel ve işitsel bir teknolojidir ve hatta bunun da ötesine geçebilme potansiyelini içinde barındırır. Sanal gerçekliğin amacı bilgisayar tarafından üretilmiş grafikler ve bilgisayar tarafından kontrol edilen seslerin olduğu bir dünya içerisinde kullanıcıyı çevrelemektir (Bolter ve diğerleri, 2006, 22). Aracın çevrelemesi ise kullanıcının aracın varlığını hissetmemesi anlamına gelir.

Televizyon (veya diğer teknolojiler) ve sanal gerçeklik arasındaki dolaysızlığı kıyaslamak için bu bölümde dolaysızlık katsayısı terimi önerilmektedir. Böylece neden ilk adım olarak sanal gerçekliğin örnek bir teknoloji olarak ele alındığı belirgin hale gelir. Televizyon canlı yayın özelliğiyle şimdi ve buradalığı vurgulamaktadır. Ancak bir televizyon izleyicisi sanal gerçeklikte olduğu gibi çevrelenmemiştir.

Televizyon hem hiper dolayımlı hem de dolaysız bir teknolojidir. Oysa sanal gerçeklik kullanıcıyı çevrelemeyi ve ona belirli bir mekanda 'olma hissi'ni verebilmeyi amaçlar. Bunu yapabilmek için de 'araçsızlaşması' gerekir. Dolayısıyla sanal gerçeklik de şimdi ve buradalığı vurgulamaktadır. 0 halde denebilir ki dolaysızlık hem bir amaç hem de bir ölçümdür. Dolaysızlık katsayısı olarak önerilen terim tam da bu ölçüme denk düşer. Özlüce, televizyonun dolaysızlık katsayısı sanal gerçekliğin dolaysızlık katsayısından düşüktür.

Sanal gerçeklik, kullanıcıyı fiziksel bir çevrede kuşatarak ona sanal, tasarlanmış bir çevrede var olma hissini verebilir. Ancak bu deneyim sırasında bilgisayar tarafından üretilmiş grafiklerde bir bozulma, bir glitch meydana geldiğinde veya seste bir arıza, gürültü ortaya çıktığında kullanıcı aslında fiziksel bir çevre içinde olduğunun farkına varabilir. Sanal gerçeklik veya daha genel anlamda dolaysızlık, kullanıcının aracı unutmasını veya aracı ortadan kaldırmak isterken, sistemde meydana gelen 
bir glitch kullanıcıya aracın varlığını hatırlatır. Glitch sanatının eleştirel tavrı tam da burada başlar. Aracın varlığı denilen şey tasarımcının veya yaratıcının parmak izleridir. Bu parmak izleri bizleri sanat dallarında modern bir pratik olarak sıkça kullanılan düşünümsel stratejiye götürür. Dolayısıyla glitch ve modern bir sanat tavrı olan düşünümsellik arasında bir bağlantı kurulabilir.

Görsel sanatlarda ve yazın sanatında düşünümsellik, aracın izlerinin ve yapım sürecinin ön plana çıkarılmasıyla ilişkilidir. Daniel Chandler ve Rod Munday, düşünümsellik kavramının bazen özdüşünümsellik olarak ifade edildiğini belirterek, "bir metnin üretim sürecinde kullanılan materyal ve teknik göstergelerini ön plana alan ve bu yüzden de metnin șeffaflığını azaltan estetik bir uygulama olarak" (2011, 361) tanımlar. Stam'e göre ise düşünümsellik "zihnin kendisini nesne olarak ele alma kapasitesidir" $(2000,151)$.

Teknoloji ve medya geliştiricileri sürekli bir biçimde aracın varlığını izleyiciye unutturmayı arzular. Bununla birlikte izleyicinin dolaysız bir enformasyon aktarımının doğrudanlığına ve varlığına inanmasını talep eder. Glitch ise ilerlemenin bu talebine karşı, yani aracın izlerinin yok edilme talebine karşı, aracın izlerini ön plana çıkarma niyetindedir. Bu niyet sinemada görülen düşünümsel tavırla ilişkilendirilebilir. Ancak bu ilişkilendirmedeki esas amaç, düşünümsel bir sinema ve glitch estetiğini aynı çerçevede değerlendirmek değildir. Bundan ziyade aracın izlerinin ortaya çıkmasının ne anlam ifade ettiği bu ilişkide açıklık kazanabilir ve bu ilişkilendirme farklı bakış açıları sunabilir.

Bir film kurmacadır, inşa edilmiş bir yapıdadır. İzleyici film süresi boyunca filmle özdeşleşebilir, aracın varlığını ve filmin inşa edilmişliğini unutabilir. Zaten klasik sinema anlatısının amacı da budur. İzleyiciyi filmin içerisine çekerek dolaysız bir etkileşim hissi yaratmaktır. Ancak modern sinemada filmin yapım süreci ve araç, bilinçli olarak ön plana çıkarılabilir. Buradaki temel amaç, izleyiciyi kurmaca ve gerçek arasında sorulara maruz bırakmaktır. Sorulara maruz kalan izleyici eserin durumuna ilişkin sistematik, bilinçli ve eleştirel bir tavır geliştirebilir.

Dolaysız bir iletişim biçimi benimseyen sayısal bir sistemde bir glitch meydana geldiği zaman, kullanıcı kendini bir anlam boşluğu içinde bulabilir. Çünkü beklenmedik bir glitch, "bir nesneyi akışından ve sıradan söyleminden, bozuma uğratılmış anlam kalıntılarına doğru kaydıran güçlü bir kesintidir” (Menkman, 2011, 29). Gürültünün yani glitchin kaynağı biliniyorsa gürültü teknik terimlerle adlandırılabilir. Ancak kaynak bilinmiyorsa gürültü kafa karıştırıcı, şok edici olabilir, aynı zamanda korku ve panik yaratabilir. İzleyicinin anlam boşluğunun içerisine düşmesinin temel nedeni bilinmezlikten gelir. Dolayısıyla bir glitch izleyiciyi şok durumuna sokarak odaklanmış bakışı dağıtır ve aracın dolaysız durumuna dikkat çekebilir. Şok etkisi, tıpkı düşünümsel filmlerde olduğu gibi, izleyiciyi araca karşı yabancılaștırabilir. Bu yabancılaştırma, sinemada geleneksel sinemanın reddine yönelik iken, bir glitch durumunda yüksek teknolojinin reddine yöneliktir. Bu reddi gerçekleştirmedeki temel uygulama ise aracın izlerini ortaya çıkarmaktır. Bir glitch, düşünümsel tavrı bir glitch çalışması üzerinde sergilerken, onun eleştirelliği teknoloji, iletişim ve medya sistemleri üzerinedir.

Bir glitch —düşünümsel bir film nasıl filmin kurmacalığına, inşa edilmişliğine, illüzyonuna dikkat çekiyorsa- aracın inşa edilmişliğine -onun izlerini ortaya çıkararak - dikkat çeker. Tıpkı Cascone'nun dediği gibi glitch, “teknoloji 
kontrolümüzün bir illüzyon olduğunu bize hatırlatır, ve aynı zamanda dijital araçların yalnızca onları üreten insanlar kadar mükemmel, hatasız ve verimli olduğunu ortaya çıkarmaktadır" $(2000,13)$. Dolaysızlık bir yanılsamaya yol açar ve kullanıcının araçla etkileşime girmesini sağlar. Bu durum kullanıcıda bir körleşme yaratır. Kullanıcı yanılsama, sanal veya simülasyon ile gerçeği bilinçli olarak birbirine karıştırır. Bir glitch ise bu yanılsamayı dağıtarak, aracın normal işleyiş biçimini değiştirerek veya onu işlevsiz hale getirerek ya da ortamı ortaya çıkararak tüketicinin sosyal gerçekliğin farkında olmasını sağlayabilir. Dağılan yanılsama ile birlikte tüketiciye medya veya içeriğe eleștirel bir bakış sunulur. Glitch, sanatsal olumsuzlamayı üretken ve yaratıcı bir güç haline dönüştürür. Anlam boşluğu içerisine düşen kullanıcı, hayal gücünü kullanmaya zorlanır. Bu parçalanma, bir glitch eserinin yorumlamaya açık ve anlamlı bir ilişki içinde olduğunu gösterir. Bu süreç boyunca "izleyicinin her anlam yaratımı yıkım eylemi kadar etkilidir" (Menkman, 2011, 42).

Dolaysızlık mantığında, aracın varlığının unutturulması kullanıcıya gerçeğe açılan pencere sunularak gerçekleștirilmek istenir. Kullanıcı bu açık pencereden dışarıya kafasını uzatabilir. Ancak hiper dolayım mantığında pencere kapalıdır, fakat izleyici pencerenin ardında olmasına rağmen pencere üzerinde temsil nesnelerini görebilir. Örnekle ifade etmek gerekirse günümüz ekranları pencereli stillerdir. Televizyon, bilgisayar, telefon gibi ekranlı sayısal sistemler hiper dolayım mantığındadır. Kullanıcıya eksiksiz bir dolaysızlık sunmazlar. Başka bir deyişle bu sistemler kullanıcıyı açık bir pencereyle tanıştırmazlar. Sanal gerçeklik ve arttırılmış gerçeklik sistemlerinde ise kullanıcı açık bir pencereyle karşı karşıya kalır. Bu yüzden kullanıcı aracın varlığını unutur, 'başka bir yerde olma' hissini yakalar.

Bir glitch ise ister dolaysızlık ister hiper dolayım mantığında olsun bu pencereleri kırar, çatlatır. Açık pencerelere de bir perde çeker. Perdelerin inmesiyle birlikte kullanıcı siyah ekranda kendi suretiyle birlikte karşı karşıya kalır. Bu an, kullanıcıda yeni bir anlayış olușturma olanağının doğduğu andır. Dolaysız temsiller sahici veya arttırılmış bir gerçeklik deneyimi sunarken, bir glitch kullanıcıyı sosyal gerçekliğin içerisine düşürür. Bir iletişim aygıtında dolaysızlık mantığı, gerçeğe açılan bir pencere veya şeffaf bir iletişim aygıtı olabileceği varsayımı taşırken, glitch bu varsayımı altüst eder. Bunu yaparken de aksaklıklardan, gürültüden ve bozulmalardan faydalanır. Dolayısıyla bu gibi aksaklıklar olumsuz olarak değil, aksine olumlu olarak dikkate alınırlar.

Dolaysızlık bir arzu iken, glitch bir sistemde beklenmeyen, istenmeyen bir aksaklıktır. Glitch, sistemin izlerini ortaya çlkararak dikkati sadece izleyicinin kendisine değil, aynı zamanda sistemin kendisine çeker. Sadece sistemin prosedürel işlevi değil, aynı zamanda sistemin üreticileri, amaçları, ideolojileri, sistemin sayısal kodları esas konu haline getirilebilir. Böylesi bir durumda izleyici/kullanıcı eleştirel bir şekilde iletişim ve medya aygıtlarının dünyayı yeterince temsil edip etmediğini sorgulamaya başlayabilir. Özlüce bir glitch, bir sistemin fark edilmemiş yönlerinin bir bütün olarak farkına varmamızı sağlayabilir. Dolayısıyla bir glitch durumunda bilgi aksaklığa, kusura, başarısızlığa veya hataya bağlıyken, dolaysız bir temsilde bilgi şeffaflığa bağlıdır.

Sanal veya arttırılmış gerçeklik gibi dolaysız temsil biçimleri gerçeğe açılan bir pencere olarak izleyiciyi, izlediği şeye yakınlaştırır ve temsil nesnesinin içerisine konumlandırır. Aksine izleyiciyi çevrelemeyen film, video gibi ekranlı görsel 
teknolojiler izleyiciyi uzakta tutar. Böylesi medya sistemlerinde meydana gelen bir glitch ise izleyiciyi ne temsile yaklaştırır, ne de temsilden uzak tutar. Aksine bir glitch radikal ve eleştirel bir şekilde, yanılsamayı kırar, temsile zarar verir veya yok eder. Kullanıcıyı ise yabancılaştırır, bir anlam boşluğuna yerleştirir. Anlam boşluğuna yerleşen kullanıcı düşünmeye sevk edilir. Glitch sanatçıları, imajı ve enformasyonu biçimsizleştirmek için kazadan faydalanırlar. Aynı zamanda anlam yaratım sürecini yorumlamak ve çözümlemek için alanlar yaratmaya yarayan anlam boşluğunu kullanırlar. Kullanıcı, sistemin izlerinin ve makinenin işleyişinin ortaya çıkarılmasıyla materyallerin, ideolojilerin ve estetik yapıların etrafında yer alarak eleştirel bir algısal deneyim elde edebilir (Menkman, 2011, 33).

Düşünümsel tekniklerde olduğu gibi, glitch estetiğinde de üretici ve tüketicinin karşılaşması üzerinde durulur. Burada amaç tüketici ve üretici arasında söylevsel bir ilişki kurmaktır. Dolaysızlık mantığında ise böyle bir ilişkiye yer yoktur, üreticinin varlığını unutturmak temel amaçtır. Bu nedenle glitch, kendisini yanılsamanın karşısında konumlandırarak mutlak gerçekliğe olan inancımıza darbe vurabilir ve üstelik teknolojik ve görsel yanılsamaya olan suç ortaklığımızı hatırlatabilir. Dolaysızlık, yüksek teknolojiden beslenirken, glitch bu teknolojiye karşı bir savaşımdır. Ancak bu savaşımı yine teknolojik olanaklarla yürütmektedir. Bu savaşım boyunca glitch, kullanıcıyı aktif bir konuma yerleștirir, sistematik ve eleştirel bir bakış açısı sunmayı amaçlar. Aktif hale gelen kullanıcının her anlam yaratımı, bir yıkım eylemi kadar etkili hale gelir. Kusursuz bir glitch ise yeni bir anlam yaratma süreci boyunca var olur (Menkman, 2011,44). Bu durum medyanın inşa edilmişliğini vurgulayan teknik bir taktiktir. Bu taktikle birlikte bir glitch, kullanıcıyı tamamen içerik değil araç üzerine, teknoloji üzerine düşünmeye zorlar. Dolayısıyla teknoloji ve ilerlemeye olan bakış açılarını çoğaltabilir.

\section{Sonuç ve Değerlendirme}

"Dolaysızlık ve Glitch Arasındaki İlişkiye Bir Bakıș” başlıklı bu çalıșmada glitch ve dolaysızlık kavramları tanımlanarak iki olgu arasındaki ilişkinin ne olduğu incelenmiştir. Bu incelemeyi yaparken yazın sanatında ve görsel sanatlarda sık sık kullanılan düșünümsellik kavramı, dolaysızlık ve glitch arasındaki ilişkinin açığa çıkarılmasına destek olmuştur. Elde edilen bulgulara göre dolaysızlık ve glitch sanat arasındaki ilişkinin iki karşıt olgu veya pratik olduğu görülmüştür. Bu bulgulardan en belirgin olanı, dolaysızlığın aracın izlerini ortadan kaldırma ve kullanıcıya araçsız bir medya deneyimi hissi yaşatma arzusuna karşın, bir glitchin aracın izlerini ön plana alarak, kullanıcıya aracın varlığını hissettirmeyle karşılık vermesidir. Elde edilen diğer bulgular ise çalışmada Dobson'ın dolaysızlık ve hiper dolayım arasındaki belirgin özellikleri sunmak için oluşturduğu tablodan ilham alınarak aşağıdaki tabloda özetlenmiştir: 
Tablo 2: Dolaysızlık ve Glitch Arasındaki İlişkiye Dair Tablo

\begin{tabular}{|l|l|}
\hline Dolaysızlık & Glitch \\
\hline Amaçtır, arzudur. & İstenmeyen, beklenmeyendir. \\
\hline Aracın izlerini yok etmeyi amaçlar. & Aracın izlerini ortaya çıkarır. \\
\hline Üretici veya yaratıcıyı gizler. & Üretici ve tüketiciyi karşı karşıya getirir. \\
\hline $\begin{array}{l}\text { Kullanıcı, psikolojik olarak aracın } \\
\text { izlerinin silindiğini hisseder. }\end{array}$ & $\begin{array}{l}\text { Kullanıcı fiziksel olarak araçla } \\
\text { karşı karşıya kalır. }\end{array}$ \\
\hline Pencere açar. & Pencereyi kırar veya perde çeker. \\
\hline Bilgi şeffaflığa bağlıdır. & Bilgi gürültüye, aksaklığa, hataya bağlıdır. \\
\hline Yanılsama yaratır. & Yanılsamayı kırar. \\
\hline Kullanıcıyı pasif konuma sokar. & Kullanıcı aktif bir konuma yerleşir. \\
\hline Eleştirel bir muhakeme yeteneğine olanak vermez. & Rahatsız eder ve sorulara maruz bırakır. \\
\hline
\end{tabular}

$\mathrm{Bu}$ tablodan teorik olarak çıkarılacak esas sonuç dolaysızlık ve glitchin birbirine karşıt iki eğilim olduğudur. Bu iki eğilim her ne kadar birbirlerine karşıt olsalar da ortak yönlerinin olup olmadığı bilinçli bir şekilde sorgulanmamıştır. Dolayısıyla bu durum sonraki araştırmalar için bir soru haline gelebilir.

Bir glitch, bir sistemde meydana gelen istenmeyen ve beklenmeyen bir hatadir. $\mathrm{Bu}$ tanım her ne kadar olumsuz gibi görünse de glitch olumlu bir olgu olarak görünmektedir. Glitch sanatçıları da, teknolojik sistemleri yapıbozuma uğratarak glitchlere ve onun olumlu yanlarına dikkat çekmek istemektedirler. Bunu yaparken de sadece estetik kaygılarla hareket etmezler. Glitch ile amaçlanan kullanıcıyı bir anlam yaratım sürecine sokmaktır. Bu süreç gerçekleştiği an, bir glitchin kusursuz hale geldiği andır. Bu durum ise glitchin eleştirelliğinin başladığı ve ötesine geçtiği bir durumu yansitır. Ancak buradaki temel sorun bir glitchin hangi durumlarda eleștirel bir biçim aldığıdır. Her glitch çalışması içerisinde bir eleştirellik barındırabilir mi? Yoksa sadece çoğu zaman göze hitap eden, ilginç gelen eserlerden ibaret olup estetik ve beğeni kaygılarıyla mı gerçekleştirilmektedir? Bunun da ötesinde bir kullanıcının teknolojik sistemlerde bir glitch ile karşılaştığında duygudurumunun ne olduğu veya genel anlamda bir glitchi nasıl alımladığı ortaya konmalıdır. Bu gibi soruları cevaplamak bu araştırmanın dışında tutulmuştur ve böylece başka araştırmalara kaynaklık edebilme potansiyeli taşırlar.

\section{Kaynakça}

American Heritage (1994). The American Heritage ${ }^{\circledR}$ Dictionary of the English Language. Boston: Houghton Mifflin.

Ballard, S. (2011). Information, Noise, et al. M. Nunes (Ed.). Error: Glitch, Noise, and Jam in New Media Cultures (s. 59-79). New York: Continuum Books.

Benjamin, W. (2012). Son Bakışta Aşk (N. Gürbilek, Çev.). İstanbul: Metis Yayınları.

Betancourt, M. (2014). Critical Glitches and Glitch Art. Erişim: 09 Mayıs 2018 A $\breve{g}$ Sitesi: http://www.hz-journal.org/n19/betancourt.html

Bolter, J. D.; Grusin, R. (2000). Remediation: Understanding New Media. Cambridge. MA: MIT Press.

Bolter, J., McIntyre, B., Gandy, M., Schweitzer, P. (2006). New Media and the Permanent Crisis of Aura. Convergence 12(1), 21-39.

Cascone, K. (2000). The Aesthetics of Failure: Post-Digital Tendencies in Contemporary Computer Music. Computer Music Journal 24(4), 12-18. 
Chandler, D., Munday, R. (2011). A Dictionary of Media and Communication. Oxford: Oxford University Press.

Dobson, S. (2006). Remediation: Understanding New Media - Revisiting a Classic. Seminar.net - International Journal of Media, Technology and Lifelong Learning, 5(2), 1-9.

Fiske, J. (2003). İletişim Çalıșmalarına Giriş (S. İrvan, Çev.), Bilim ve Sanat: Ankara.

Grammatikopoulou, C. (2014). The wilderness in the machine: Glitch and the poetics of error. Erişim tarihi: 24 Mayıs 2018 A $\breve{g}$ Adresi: https://interartive. org/2014/01/glitch-art

Grundell, V. (2016). Flow and Friction: On The Tactical Potential Of Interfacing With Glitch Art. Malmö: Holmbergs.

Güngör, N. (2013). İletişim / Kuramlar ve Yaklaşımlar. Ankara: Siyasal Kitabevi.

McQuail, D. \& Windahl, S. (2005). İletişim Modelleri (K. Yumlu, Çev.), Ankara: İmge Kitabevi.

Menkman, R. (2011). Glitch Moment(um). Amsterdam: Institute of Network Cultures.

Mennasemay, M., Milkman, K., Krishtalka, A., Shoemaker, R., Katz, A. (2017). GL.TCH. A. Beattie; F. Mulvey (Ed.). [Elektronik Sürüm]. Erișim Tarihi: 15 Mayıs 2018 Ă Adresi: https://issuu.com/dawsonspace/docs/gl.tch_catalog-issuu_ march14-lowres

Moradi, I. (2004). Glitch Aesthetics, Yüksek Lisans Tezi, University of Huddersfield, Huddersfield, UK.

Motherboard (2002). Glitch. Erişim Tarihi: 29 Mayıs 2018 Ağ Adresi: http://www. liveart.org/motherboard/glitch/

Nunes, M. (2011). Error, Noise, and Potential: The Outside of Purpose. M. Nunes (Ed.). Error: Glitch, Noise, and Jam in New Media Cultures (s. 3-23) New York: Continuum Books.

Özçetin, B. (2018). Kitle İletişim Kuramları: Kavramlar, Okullar Modeller. İstanbul: İletişim Yayınları

Shannon, C. E. (1948). A Mathematical Theory of Communication. The Bell System Technical Journal, 27(3), 379-423.

Somer, H. S. (2013). Sayısal Medya Sanatı Olarak Glitch Sanatı ve Etkileri. Erişim Tarihi: 08 Mayıs 2018 A $\breve{g}$ Adresi: http://www.sayisalmimar.com/kurslar/ bs503/makaleler/bs503_201314_sarp.pdf

Stam, R. (2000). Film Theory: An Introduction. Maiden: Blackwell Publishers Inc. 